\title{
コイルばねを用いた小型免震テーブルの研究
}

\author{
松岡 太- ${ }^{* 1}$, 高柳 天馬 ${ }^{* 2}$, 丹羽 智紀 ${ }^{* 3}$, 大亦 絢一郎 ${ }^{* 4}$
}

\section{Study on small seismic isolation table using coil springs}

\author{
Taichi MATSUOKA ${ }^{* 1}$, Tenma TAKAYANAGI ${ }^{* 2}$, \\ Tomonori NIWA $^{* 3}$ and Kenichiro OHMATA ${ }^{* 4}$

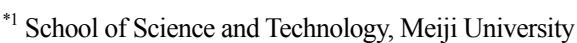 \\ 1-1-1 Higashimita, Tama-ku, Kawasaki-shi, Kanagawa 214-8571, Japan \\ ${ }^{* 2}$ GERB Japan \\ 1-4 Tsutsumicho, Hiratsuka-shi, Kanagawa 254-0027, Japan \\ ${ }^{* 3}$ Dept. Mechanical Engineering Informatics, School of Science and Technology, Meiji University \\ 1-1-1 Higashimita, Tama-ku, Kawasaki-shi, Kanagawa 214-8571, Japan \\ ${ }^{*}$ Professor Emeritus of Meiji University \\ 1-1-1 Higashimita, Tama-ku, Kawasaki-shi, Kanagawa 214-8571, Japan
}

\section{Received 17 November 2014}

\begin{abstract}
In this paper, a new type of small seismic isolation table using coil springs, which has a simple construction and the capability of vibration isolation in every horizontal direction, is proposed. A table board supported with roller bearings is pulled almost vertically toward a base board with four coil springs. The coil springs give horizontal restoring force and friction force to the table board when the table moves relatively to the base board. The trial small seismic isolation table is manufactured, and the resisting force characteristics are measured. The numerical results are derived theoretically and compared with the experimental results. Harmonic response test and seismic response tests are carried out by using a shaking table in order to confirm the effect of vibration isolating under some earthquakes that have several periodic component. The experimental and calculated results show that the maximum response accelerations of the table board with a loaded mass decreased to about 1/10 1/12 compared to those without the isolation table.
\end{abstract}

Key words : Seismic isolation, Isolation table, Coil spring, Friction damper, Seismic response

\section{1. ま え がき}

1983 年に日本で初めて建設された免震建物は，1995 年に発生した兵庫県南部地震の翌年に急激に増加し，現在 では免震ビルのみならず戸建て免震住宅も多数建設されている. 免震建物の開発と並行して，いろいろなタイプ の機器用水平免震テーブル（藤田他，1984，藤田他，1993，上田他，2005，新谷他，2007），および三次元免震テ ーブル（藤田他，1985，藤田他，1990，Takahashi, et al., 2005）が開発され，そのいくつかは実際に博物館や美術 館などで使用されている. 著者らもいくつかのタイプの水平免震テーブル (大亦他, 2002, 古平他, 2005), およ び三次元免震テーブル（上田他，2007，若林他，2010a）を開発した．現在実用化されている免震テーブルは，い ずれも免震効果は高いが，構造がやや複雑なものや精密なものが多く，值段が高いという久点を持っている.

本研究では，小型の機器，家具，美術品を対象とした安価で免震効果が高い小型免震テーブルを得ることを目 的として，コイルばねと転がり支承を用いた簡単な構造の水平免震テーブルを提案する。コイルばねを垂直に使 用する免震建物は深沢ら（深沢他，2008）によって提案されているが，本研究では 4 本のコイルばねを上下方向

No.14-00607 [DOI: 10.1299/transjsme.14-00607], J-STAGE Advance Publication date : 14 April, 2015

*1 正員，明治大学理工学部（干214-8571 神奈川県川崎市多摩区東三田 1-1-1）

*2 ゲルブ・ジャパン (株)（†254-0027＼cjkstart神奈川県平塚市堤町 1-4）

*3 明治大学理工学部機械情報工学科 (現クリナップ (株))

*4 正員, フェロー，明治大学名誉教授

E-mail of corresponding author: matsuoka@meiji.ac.jp 
Matsuoka, Takayanagi, Niwa and Ohmata, Transactions of the JSME (in Japanese), Vol.81, No.825 (2015)

に傾けて使用することにより, テーブル板に水平方向の復元力と減衰力 (摩擦力) を与えようとするものである. 本免震テーブルを試作し，その抵抗力特性を理論解析と実験により調べる. 次に，本免震テーブル上に集中質量 を搭載した場合について，振動台を用いた周波数応答実験と地震波加振実験，およびそれらの解析を行い，本免 震テーブルの免震効果および解析の妥当性を確認する．また，長周期地震動対策についても言及する.

\section{2. 免震テーブルの構造}

本研究で提案する水平免震テーブルを図 1 に示す. 本免震テーブルは，テーブル板，テーブル板の四隅に取り 付けた支持棒（脚），各支持棒の先端に取り付けたフリーベア（転がり支承）から成るテーブル部と，基礎板，基 礎板の上に貼り付けた薄いステンレス板から成る基礎板部，およびこれら二つの部分を繋ぐ4 本のコイルばねに よって構成されている. 4 本のコイルばねは，予め引張りを与えられた状態で，図 1 に示すようにテーブル部と 基礎板部間に傾けて取り付けられている. テーブル板が基礎板に対して相対的に水平方向に移動すると，テーブ ル板はコイルばねに作用するばね力の水平方向成分によって復元力を受け，ばね力の垂直成分によってフリーベ アを通して摩擦力および粘性摩擦力を受ける。コイルばねを少し傾けて取り付けてあるのは，免震テーブルの移 動範囲を広くするためである.テーブル板および基礎板は共に正方形状であり，4 本のコイルばねはテーブル板 と基礎板の中心に対称的に配置されている. 各ばねの両端は，水平面内の回転運動（ヨーイング）が生じないよ うに，回転自由に取り付けられている．また，本免震テーブルは背の高い構造となっているが，免震されること によって搭載機器の慣性力は小さくなり，コイルばねがテーブル板を下方に押さえつけているので，スリムで重
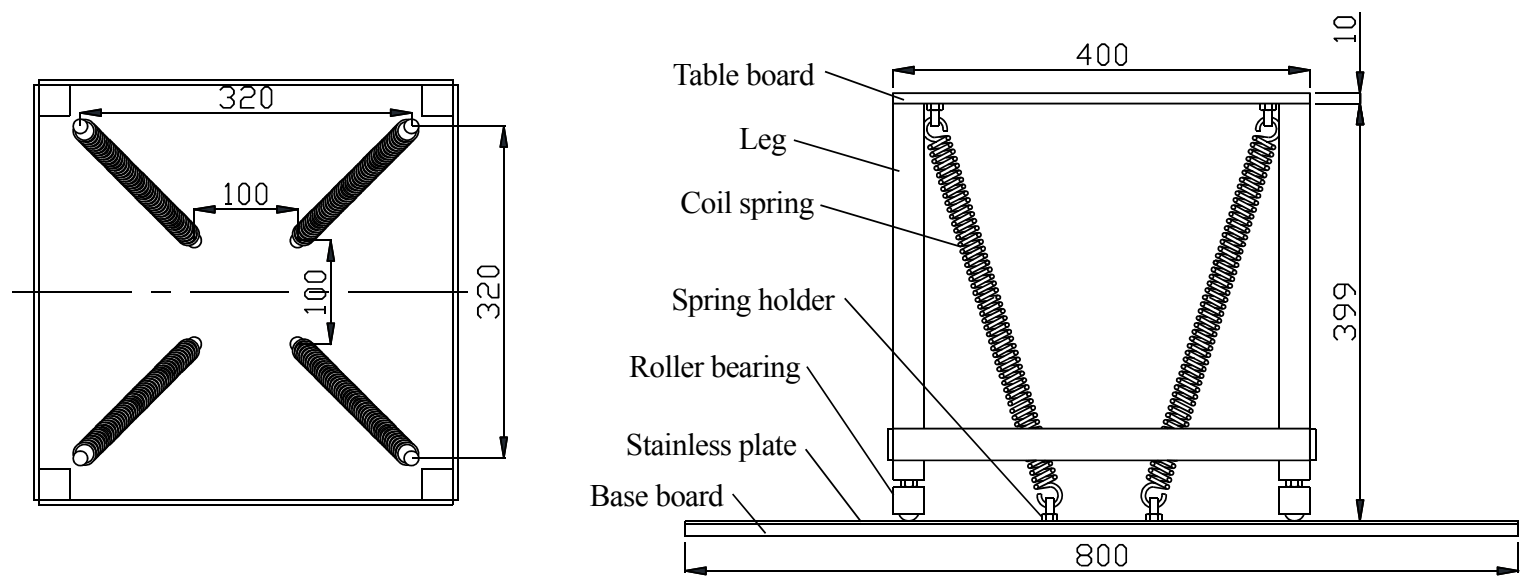

Fig. 1 Assembly diagrams of the small seismic isolation table. Four coil springs are attached between the table board and the base board with angle and pretension. Four free bearings are installed at the bottom of the legs, and they are able to move smoothly in any horizontal directions on the stainless plate.

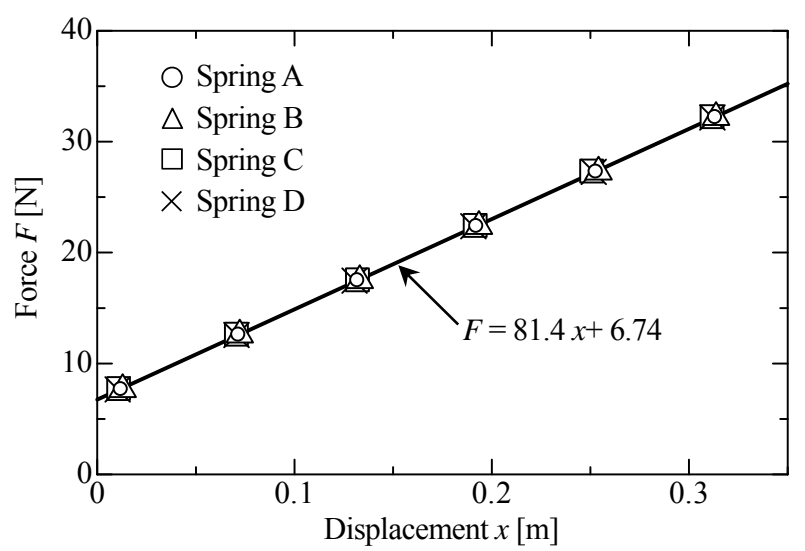

Fig. 2 Static force characteristics of each coil spring. The spring constant becomes $81.4 \mathrm{~N} / \mathrm{m}$, and the initial tension becomes 6.74 $\mathrm{N}$ in average. 
心の高い機器を除くと，ロッキング運動が起こりにくく転倒の心配は少ない．使用した 4 本のコイルばねは同じ 復元力特性を持ち, 各ばねの静的試験結果を図 2 に示寸. これより, ばねを引っ張ったときの初張力（密着して いる線材を引き離す力）は $T_{0}=6.74 \mathrm{~N}$, ばね定数は $k=81.4 \mathrm{~N} / \mathrm{m}$ である.

\section{3. 抵 抗 力特 性}

\section{$3 \cdot 1$ 解析モデル}

本免震テーブルの抵抗力特性解析モデルを図 3 に示す. 図 3 は $x$ 方向に対寸る解析モデルであるが, $y$ 方向に 対する解析モデルも同じであるので，ここでは $x$ 方向についてのみ述べる．各コイルばね（引張りばね）のばね 定数を $k$, 初期長さを $L_{0}$, 予引張り量を $\delta_{0}$, 初張力を $T_{0}$, ばねに加えられた初期引張り力を $T_{s}\left(=T_{0}+k \delta_{0}\right)$, 初期 状態でコイルばねを基礎板に投影したときの $x, y$ 方向の長さ成分を $a, b$, テーブル板の高さを $h$, 転がり支承と 基礎板の間の摩擦係数を $\mu$ とする. テーブル板が $x$ 方向に相対変位 $u$ だけ移動すると, 右側と左側のコイルばね の長さは $L_{1}, L_{2}$ に変化する．これによって右側と左側のコイルばねの追加伸びは $\delta_{1}, \delta_{2}$ となり,$x$ 方向の復元力 は $p_{1}, p_{2}$, 下向きの押付け力は $s_{1}, s_{2}$ となる. 図 3 から幾何学的に $L_{0}, L_{1}, L_{2}, \delta_{1}, \delta_{2}$ は次式で表される.

$$
\left\{\begin{array}{l}
L_{0} \\
L_{1} \\
L_{2} \\
\delta_{1} \\
\delta_{2}
\end{array}\right\}=\left\{\begin{array}{c}
\sqrt{a^{2}+b^{2}+h^{2}} \\
\sqrt{(a+u)^{2}+b^{2}+h^{2}} \\
\sqrt{(a-u)^{2}+b^{2}+h^{2}} \\
L_{1}-L_{0} \\
L_{2}-L_{0}
\end{array}\right\}
$$

4 本のコイルばねによる $x$ 方向の復元力 $F_{s}$ は

$$
F_{s}=2\left(p_{1}-p_{2}\right)=2\left\{\frac{k \delta_{1}+T_{s}}{L_{1}}(a+u)-\frac{k \delta_{2}+T_{s}}{L_{2}}(a-u)\right\}
$$

および摩擦力 $P_{c}$ は

$$
P_{c}=2 \mu\left(s_{1}+s_{2}\right) \operatorname{SIGN}(\dot{u})=2 \mu h\left(\frac{k \delta_{1}+T_{s}}{L_{1}}+\frac{k \delta_{2}+T_{s}}{L_{2}}\right) \operatorname{SIGN}(\dot{u})
$$

と表せる．式(3)に，搭載質量を含むテーブル部の質量 $m$ による摩擦力を加えた全摩擦力 $F_{c}$ は

$$
F_{c}=\mu\left\{2 h\left(\frac{k \delta_{1}+T_{s}}{L_{1}}+\frac{k \delta_{2}+T_{s}}{L_{2}}\right)+m g\right\} \operatorname{SIGN}(\dot{u})
$$

ここで, $\operatorname{SIGN}(\dot{u})$ は $の$ 負, 正に応じて $-1,1$ の值を取る符号関数である. 次に, 図 3 の右側のコイルばねを考え る. コイルばねの上端（B点）が初期位置から $x$ 方向に $-a, y$ 方向に- $b$ だけ移動すると, コイルばねの長さは最

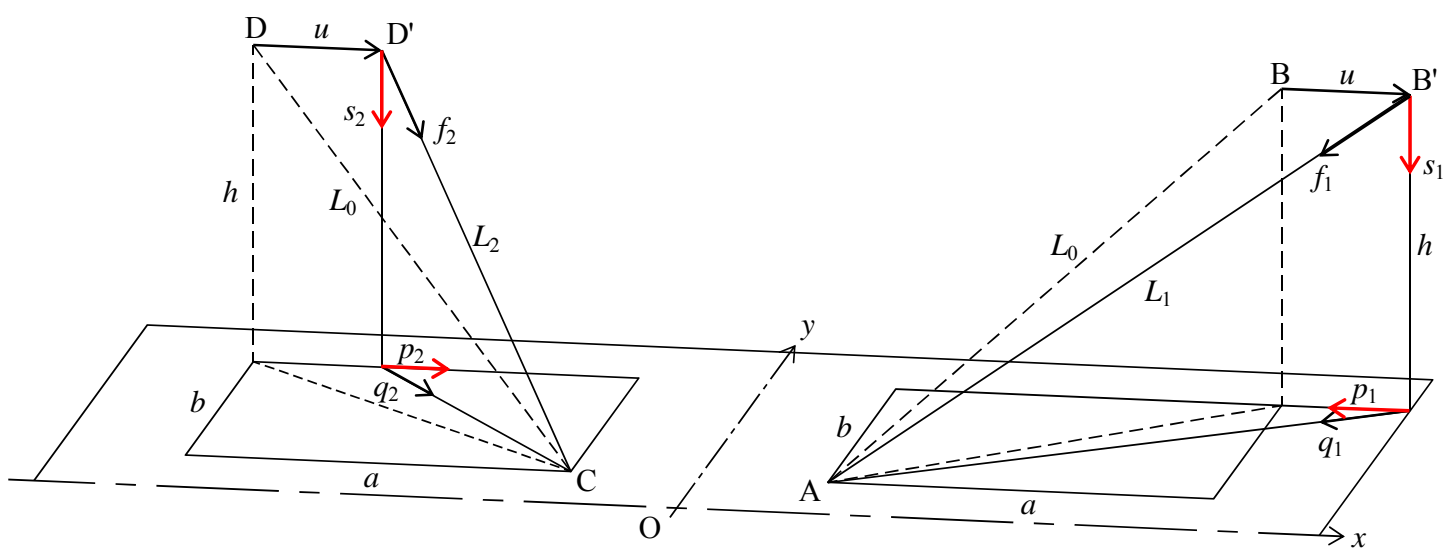

Fig. 3 Geometric diagram of the forces when the table board is displaced. 
短となる (コイルばねは垂直の状態となる)。このときのコイルばねの長さはほぼhであるから，コイルばねを常 に引張状態にしておくための予引張り量 $\delta_{0}$ の最小值は, 次式で与えられる.

$$
\left|\delta_{0}\right|_{\min }=L_{0}-h
$$

また，初期状態における水平方向の復元力定数（ば叔定数） $k_{0}$ は

$$
k_{0}=\frac{4 T_{s}}{L_{0}}
$$

および摩擦力 $F_{0}$ は

$$
F_{0}=\mu\left(\frac{4 h T_{s}}{L_{0}}+m g\right)
$$

と表せる. 式(2)を用いて変位 $u$ と復元力 $F_{s}$ の関係を計算すると, 図 4 のようになる. また, 式(4)を用いて $u$ と 全摩擦力 $F_{c}$ の関係を計算すると, 図 5 のようになる. これらの計算に用いた諸元は試作した免震テーブルの值で あり，その值を表 1 に示寸. 図 4,5 には， $\delta_{0}=0$ の場合 $\left(T_{s}=6.74 \mathrm{~N}\right.$ の場合）も合わせて示してある. 図 4,5 から分かるように, 復元力特性および摩擦力特性は, いずれも漸硬型特性を示している. 一般に, 免震テーブル は 0.2 1 秒程度の短周期成分が卓越した地震動を対象としており, 高い免震効果を得るために, 免震テーブルの 固有周期を $2 \sim 5$ 秒に設定し，減衰を小さめに設定している場合が多い.したがって，これらの免震テーブルに 2 ～5 秒の卓越周期成分を含む長周期地震動が作用したときには，免震テーブルは共振し，許容変位を越えるほど 大きく振動することになる. このような免震テーブルの共振に対して, 漸硬型復元力特性は共振をずらすのに役 立ち, 漸硬型摩擦力特性は共振を抑制するのに役立つ (若林他, 2010b). したがって, 図 4, 5 の復元力特性およ び摩擦力特性は，免震テーブルにとって望ましい特性と言える.

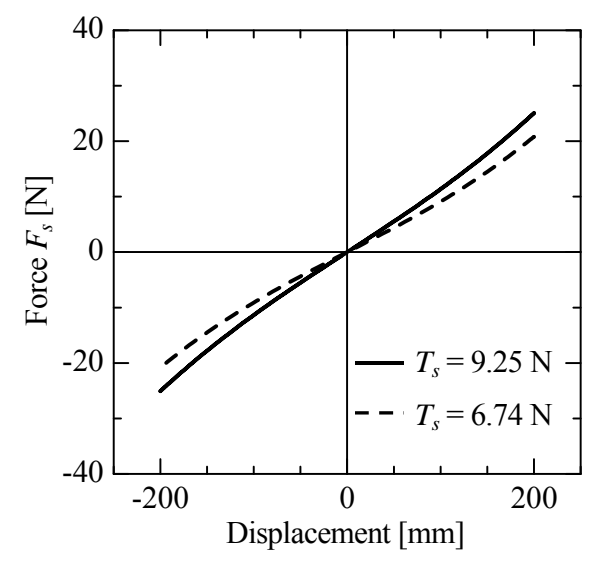

Fig. 4 Restoring force characteristics. The stiffness becomes harder as displacement increases.

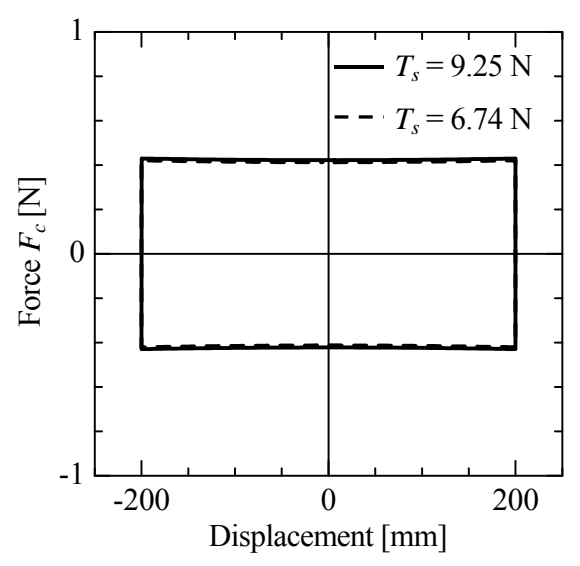

Fig. 5 Friction force characteristics. The forces slightly decrease at the center position.

Table 1 Design parameters of the trial small seismic isolation table.

\begin{tabular}{lll}
\hline Length & $a$ & $0.11 \mathrm{~m}$ \\
& $b$ & $0.11 \mathrm{~m}$ \\
& $h$ & $0.374 \mathrm{~m}$ \\
\hline Spring stiffness & $k$ & $81.4 \mathrm{~N} / \mathrm{m}$ \\
Initial tension & $T_{0}$ & $6.74 \mathrm{~N}$ \\
Initial elongation & $\delta_{0}$ & $0.031 \mathrm{~m}$ \\
Initial tensile force & $T_{s}$ & $9.25 \mathrm{~N}$ \\
Coefficient of friction & $\mu$ & 0.001 \\
Table board total mass & $m$ & $39.5 \mathrm{~kg}$ \\
Damping coefficient & $c$ & $3 \mathrm{Ns} / \mathrm{m}$ \\
\hline
\end{tabular}




\section{$3 \cdot 2$ 抵抗力測定実験}

試作した免震テーブルの復元力, 摩擦力, 減衰力特性を調べるために，テーブル部（質量 $9.5 \mathrm{~kg}$ ）に $30 \mathrm{~kg}$ の集 中質量を搭載し, クランク機構式水平振動台により振幅 $45 \mathrm{~mm}$, 振動数 $0.5 \mathrm{~Hz}$ の正弦波状変位を与えて免震テー ブルの抵抗力を測定した．実験装置を図 6 に示す．この場合，ロードセルには式(2)，(4)で与えられるばね力 $F_{s}$ と摩擦力 $F_{c}$ の他に，フリーベアの粘性減衰力 $F_{v}(=c \dot{u})$ も作用し，全作用力 $F$ は次式で与えられる.

$$
F=F_{s}+F_{c}+F_{v}
$$

ここで，装置全体の粘性減衰係数は，振動数（すなわち速度）を変化させたときの抵抗力の変化より同定し， $c=$ $3 \mathrm{Ns} / \mathrm{m}$ 程度であった．実験結果と計算結果を合わせて図 7 に示寸，実験では，振動台を水平に振動させているに もかかわらず上下振動も生じており，図７の実験結果には，振動台の上下振動によって生じる摩擦力や粘性減衰 力の変化の影響が現れている．しかしながら平均的に見れば，実験值と計算值はほぼ一致しており，計算に使用 した諸元の正しさが確認できる.

\section{4. 振 動 実 験}

\section{$4 \cdot 1$ 解析モデル}

本免震テーブルは $x$ 方向と $y$ 方向で同じ振動特性を持つため, $x$ 方向と $y$ 方向の振動解析モデルは同じになる. ここでは，免震テーブルの基本的な免震特性を知るために，免震テーブルの $x$ 方向に地震波の南北（NS）成分を 入力してテーブルの応答を調べることにした. 周波数応答解析および地震波応答解析に用いた免震テーブルの $x$ 方向解析モデルを図 8 に示す. 入力加速度を $\ddot{z}_{x}$ とすると運動方程式は

$$
m \ddot{u}+c \dot{u}+F_{s}+F_{c}=-m \ddot{z}_{x}
$$

と表せる. 上式を MATLAB/Simulink を用いて数值計算を行った.

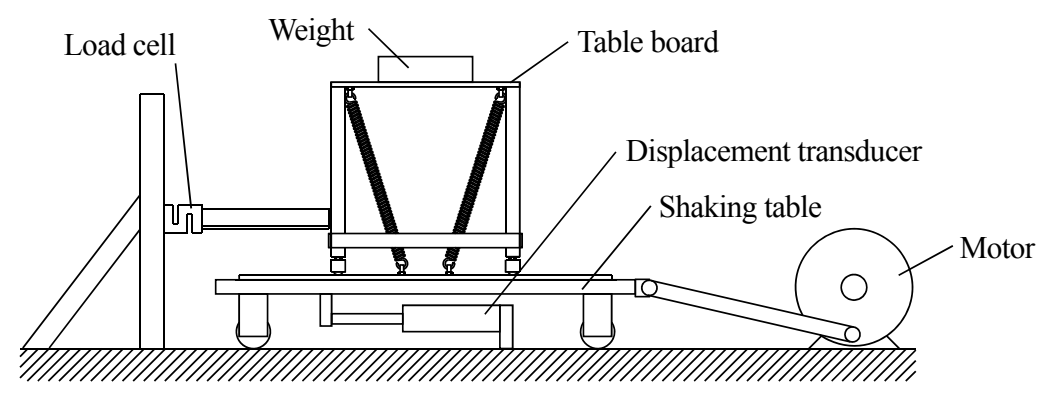

Fig. 6 Experimental setup. This shaking table can cause horizontally sinusoidal wave by a slider crank mechanism. Concentrated mass of $30 \mathrm{~kg}$ is put on the table board.

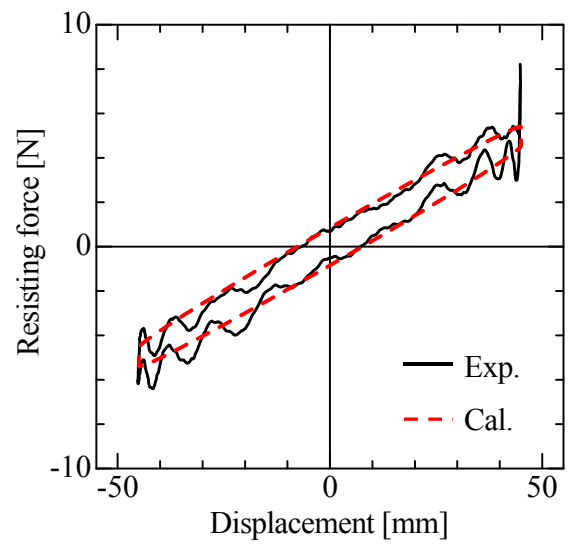

Fig. 7 Resisting force characteristics of the trial isolation table in case of $0.5 \mathrm{~Hz}$. The experimental result is matched to the theoretical result which is derived from Eq. (8). 


\section{$4 \cdot 2$ 周波数応答実験}

テーブル部の質量を含めて $39.5 \mathrm{~kg}$ の集中質量を搭載した免震テーブルを振動台に取り付け, 正弦波状の加速度 を $x$ 方向に $0.1 \mathrm{~Hz}$ から $1.0 \mathrm{~Hz}$ まで入力し，テーブル板の絶対加速度をサーボ加速度計で，テーブル板と振動台の 絶対変位をレーザー变位計により測定した．実験装置の外観を図 9 に示す．実験装置の諸元は表 1 に示した通り であり，免震テーブルの固有振動数は理論的には $0.26 \mathrm{~Hz}$ である.

実験結果を計算結果と合わせて図 10 に示す．図 10 の縦軸は，絶対変位比（テーブル変位／振動台変位）を表 す. 図 10 より，実験值と計算值がある程度一致していることがわかる．しかし，共振点におけるピーク值に差異 が生じていることがわかる.これは摩擦の影響により振動系全体の減衰比が増したためと考えられる. 摩擦力に よる等価粘性減衰比は 0.08 程度であり, フリーベア 4 個のみの場合を上回っている.

\section{$4 \cdot 3$ 地震波応答実験}

周波数応答実験と同じ実験装置を用い, 振動台に最大加速度を $1 \sim 4 \mathrm{~m} / \mathrm{s}^{2}$ に基準化した Imperial valley 地震(1940) El Centro NS 成分，および兵庫県南部地震（1995）神戸海洋気象台 NS 成分を $x$ 方向に入力して，テーブル板と振 動台の加速度および絶対変位を測定した．加速度の測定にはサーボ型加速度計を用いた．また，テーブル板と振 動台の相対変位は，それぞれの絶対変位の差分である.

最大加速度を $4 \mathrm{~m} / \mathrm{s}^{2}$ に基準化した El Centro 波および神戸海洋気象台波を入力したときの応答加速度波形と相対 変位波形を式(9)から得られる計算值と合わせて，それぞれ図 11 および図 12 に示す．また，最大入力加速度毎の 最大応答加速度の実験值と計算值を合わせて図 13 に示す. 図 11,12 から, 最大応答加速度は最大入力加速度に 比べて, El Centro 波入力時で約 1/12 に低減し，神戸海洋気象台波入力時で約 1/10 に低減することが分かる.ま た図 13 から, 免震テーブルの免震効果（最大加速度の低減効果）は, 入力加速度が大きい時ほど大きくなること が分かる. 図 11〜13 から分かるように, 計算結果は実験結果と似た傾向を示しており, 解析の妥当性が確認され た．計算值と実験值の違いは，主に計算值が停滞運動を考慮していないこと，および計算に用いた摩擦力が実際

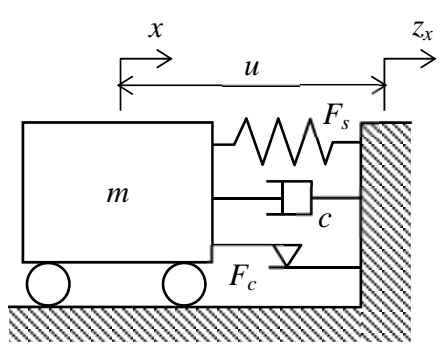

Fig. 8 Analytical model in $x$ direction.

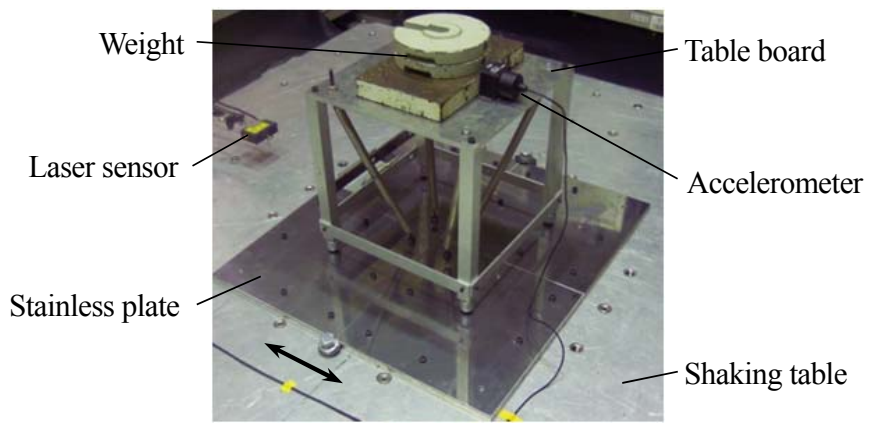

Fig. 9 Experimental setup.

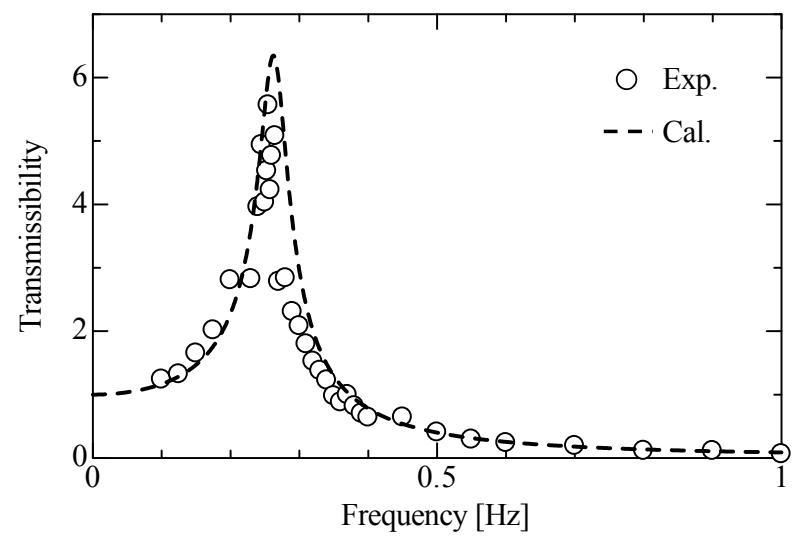

Fig. 10 Harmonic response curve. The natural frequency becomes $0.255 \mathrm{~Hz}$, and the damping ratio becomes 0.08 in the experiment. 


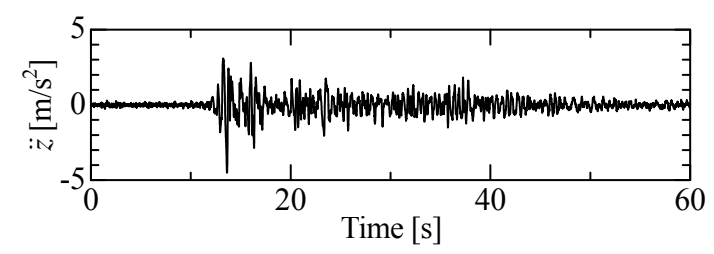

(a) Input acceleration
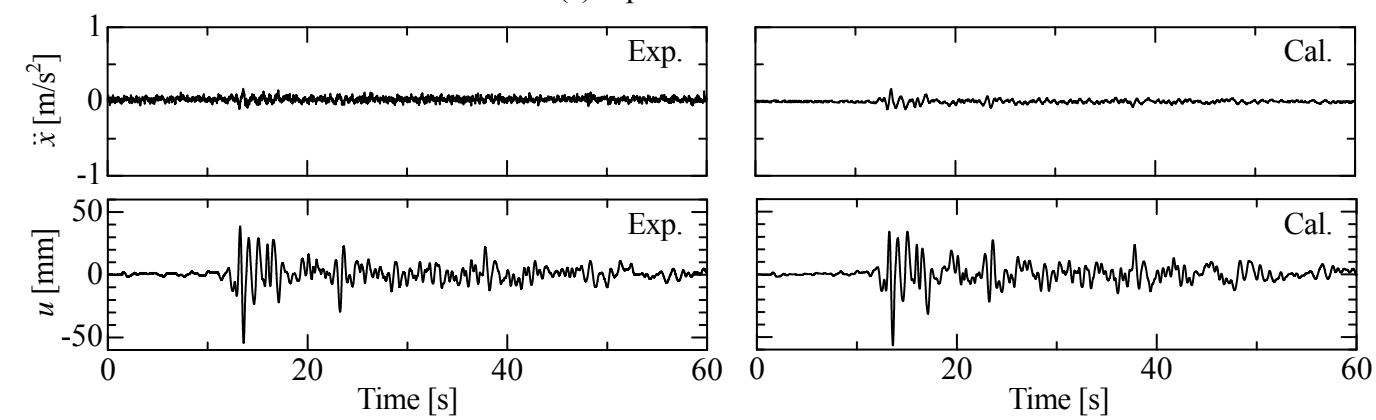

(b) Response acceleration and relative displacement

Fig. 11 Seismic response waveforms when El Centro north-south component normalized to be $4 \mathrm{~m} / \mathrm{s}^{2}$ at the maximum acceleration was inputted. The peak acceleration decreases about $1 / 12$.

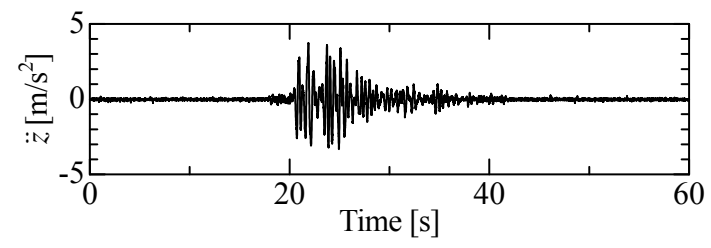

(a) Input acceleration
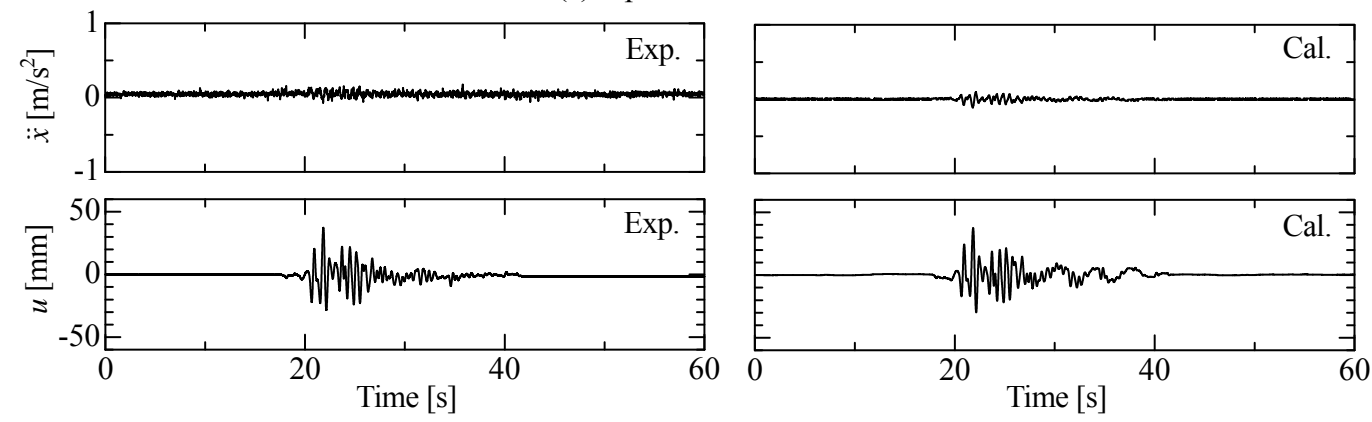

(b) Response acceleration and relative displacement

Fig. 12 Seismic response waveforms when JMA Kobe north-south component normalized to be $4 \mathrm{~m} / \mathrm{s}^{2}$ at the maximum acceleration was inputted. The peak acceleration decreases about 1/10.
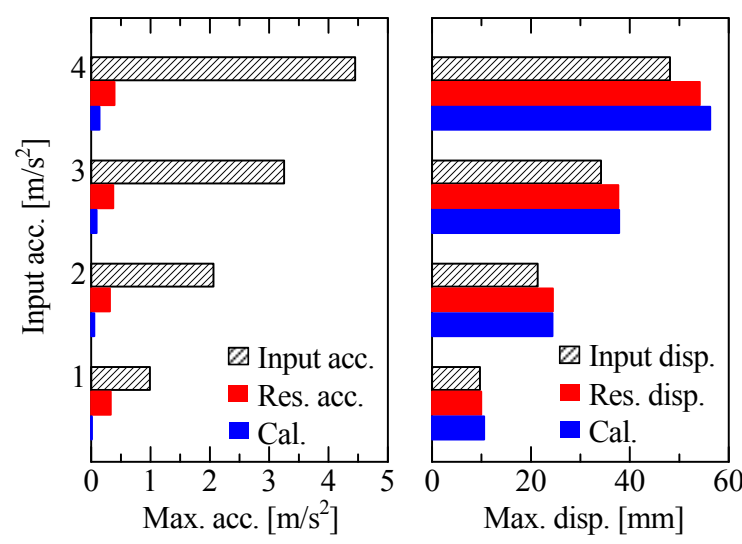

(a) El Centro
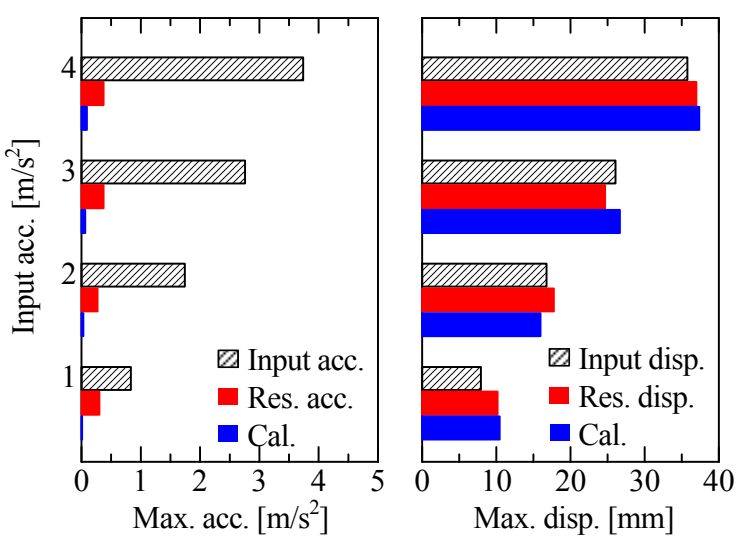

(b) JMA Kobe

Fig. 13 Peak response values of acceleration and relative displacement. Vibration can be isolated enough at larger seismic levels. The experimental results of relative displacement are well matched to the calculated results. 
よりも小さかったためと思われる. 実験は数回ずつ繰り返し行われたが, 実験結果は安定した免震効果を示した.

\section{$4 \cdot 4$ 長周期成分を含む地震動に対する対策}

前節の地震波応答解析で用いた地震波は, 周期 1 秒以下の比較的短周期成分が卓越した通常の地震波であった. しかしながら，本免震テーブルの固有周期（搭載質量 $39.5 \mathrm{~kg}$ 時は 4 秒）に近い長周期卓越成分を含む地震波が作 用すると，本免震テーブルは共振を起こし，テーブルが大きく振動する恐れがある，そこで，比較的に長周期の 卓越成分を持つ新潟地震 (1964) NS 成分が本免震テーブルの基礎部 $x$ 方向に作用した場合について実験と解析を 行い, その影響について調べた. 本実験で用いた 3 種類の地震波 NS 成分（El Centro 波, 神戸海洋気象台波, 新 潟波）のスペクトルを比較したものを図 14 に示寸. なお，振動台の仕様により，低振動数領域はフィルタ処理さ れている. 図 14 より，El Centro 波は振動数が $0.7 \mathrm{~Hz}$ 以上（周期 1.4 秒以下），および神戸海洋気象台波は同 $1 \mathrm{~Hz}$ 以上（同 1 秒以下）の短周期卓越成分のみを持つが，新潟波は同 $0.25 \sim 0.3 \mathrm{~Hz}$ と比較的長周期の $3 \sim 4$ 秒前後に卓 越成分を持つことがわかる. 免震テーブルの搭載質量を $29.5 \mathrm{~kg}$ （固有周期を 3.3 秒）とした場合, 本免震テーブ ルが新潟地震 NS 成分を受けると，共振を起こす可能性がある.

そこで，長周期成分入力時における免震テーブルの共振を防ぐための対策を二つ示す．一つはダンパの発生力 を増すことである，例えば，図 15(a)に示すような摩擦ダンパを追加すればよい，ただし，ダンパを強くすると， 短周期成分が卓越した通常の地震動に対する免震効果は低下してしまう。二つ目は, 通常の地震波に対する免震 効果を低下させることなく長周期地震動による共振を抑制することである. 既報（若林他，2011）および $3 \cdot 1$ 節 で述べたように，ばね力と摩擦力をある程度強い漸硬型にすればよい，本免震テーブルの場合は，図 4 に示すよ うなばね力, 摩擦力とも弱い漸硬性を持っているが, 図 15(b)に示すような基礎板の周りに設置した保護板の内側 に, ウレタンフォームのような緩衝材を接着すると, 更に強い漸硬型となる. 寸なわち, 免震テーブルの振動が 大きくなると支持棒が緩衝材に接触し, 変位と共に免震テーブルのばね力と摩擦力が漸硬的に増大寸る. 本報で は, 図 15(a)のブレーキシューを取り付けて実験を行った。

最大加速度を $4 \mathrm{~m} / \mathrm{s}^{2}$ に基準化した新潟波を入力したときの応答加速度波形と相対変位波形を計算值と合わせて 図 16 に示し, 最大加速度を 1 4 m/s $\mathrm{s}^{2}$ に基準化した新潟波入力時における最大応答加速度の実験值と計算値を合

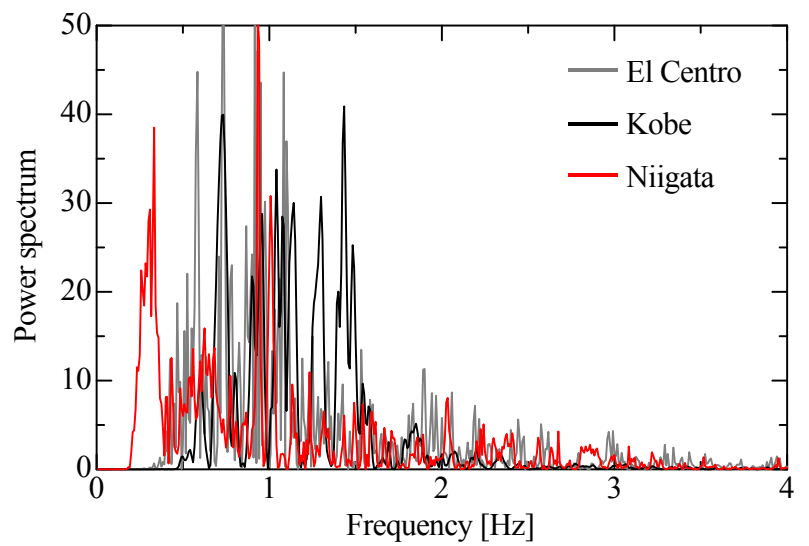

Fig. 14 Power spectrums of the input accelerations. Wave of Niigata has a long periodic component comparatively to the others.

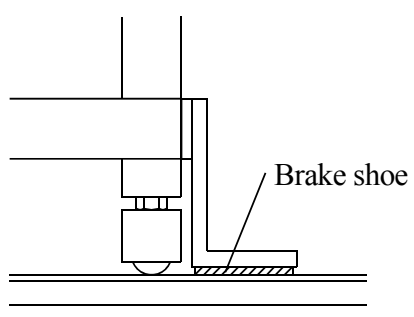

(a) Friction damper

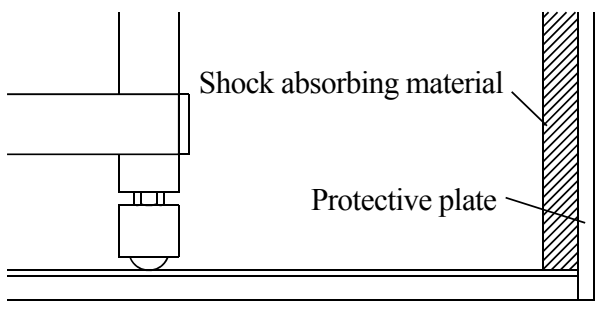

(b) Shock absorbing material

Fig. 15 Improvements for long period seismic ground motions. 


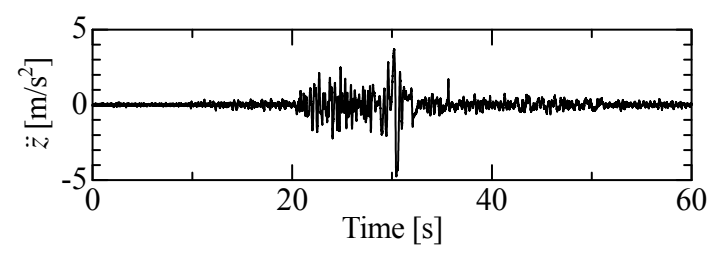

(a) Input acceleration
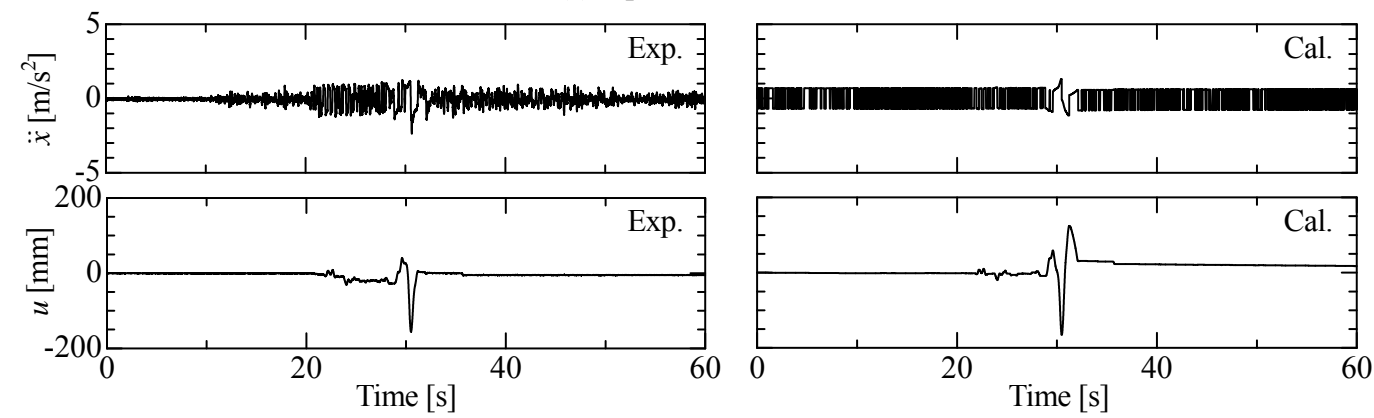

(b) Response acceleration and relative displacement

Fig. 16 Seismic response waveforms with friction dampers when Niigata north-south component normalized to be $4 \mathrm{~m} / \mathrm{s}^{2}$ at the maximum acceleration was inputted. The peak acceleration decreases about $1 / 2$. The friction damper is available for a resonance caused by a long period seismic component.
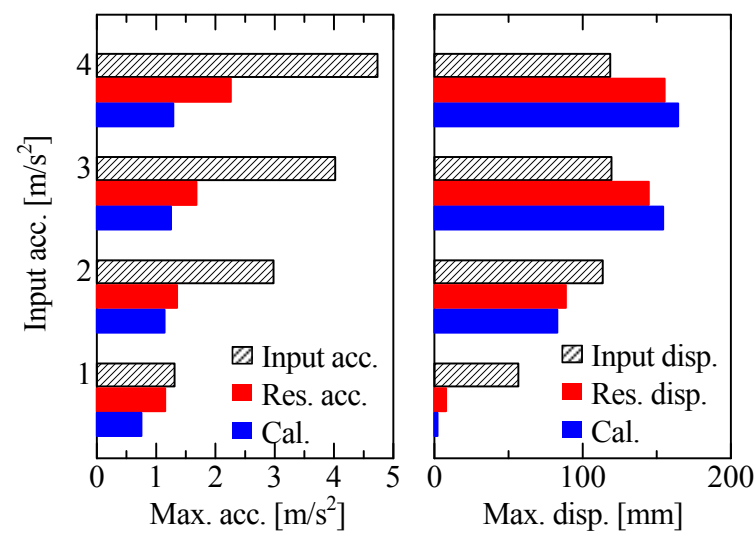

Fig. 17 Peak response values of acceleration and relative displacement in case of Niigata north-south component. The relative displacements become larger than the others due to a long period seismic component.

わせて図 17 に示す. 計算は式(9)にブレーキシューによる一定の摩擦力を $20 \mathrm{~N}$ とて付け加えた. 図 16 から最 大応答加速度は最大入力加速度に比べて約 $1 / 2$ に低減されていることがわかる．同時に，相対变位も低減してお り，脱輪は確認されなかった。 ちなみに，ブレーキシューを取り付けていない場合の実験も行ったが，テーブル 板が共振して大きく振動し，フリーベアがステンレス板から脱輪したことを確認している．また，図 17 から，比 較的大きな入力加速度において免震効果が生じていることから，長周期成分を含んだ地震動に対して効果的であ ることが分かった。

\section{5. ま と め}

本研究では，フリーベアを有する 4 本の支持棒で支えられたテーブル板部と，基礎板部，およびテーブル板部 と基礎板部を繋ぐ 4 本のコイルばねから成る小型免震テーブルを提案した。この免震テーブルを試作し，その復 元力特性を理論解析と実験によって確かめた. 次に, テーブル板に集中質量を搭載したときの免震効果を, 周波 数応答実験および地震波応答実験とそれらの解析により確認した. 主な結果は以下の通りである.

(1) 本免震テーブル基礎部に El Centro NS 成分および神戸海洋気象台 NS 成分を $4 \mathrm{~m} / \mathrm{s}^{2}$ 基準化して入力すると, 最大応答加速度は入力加速度の $1 / 12 \sim 1 / 10$ に低減する. この免震効果（最大加速度低減効果）は，入力加速 
度が小さくなると低下寸る.

（2）抵抗力特性，周波数応答および地震応答実験の結果は計算結果と似た傾向を示し，理論および解析の妥当性 が確かめられた。

（3）本免震テーブルに 3 4 秒の長周期卓越成分を含む新潟地震波（1964）を入力したところ，テーブル板は大き く共振した．この共振を抑制するためには摩擦ダンパが有効であることを，実験と計算により確認した.

\section{文献}

藤田聡，森川裕一，下田郁夫，長田修一，下坂陽男，球面すべり支承を用いた機器免震装置に関する研究（第 1 報，免震支持された系についての振動実験と応答解析，日本機械学会論文集 C編，Vol. 59，No. 557 (1993)， pp. 11-16.

藤田隆史，鞍本貞之，小見俊夫，三次元免震装置の研究，日本機械学会論文集 C 編，Vol. 51，No. 471（1985）, pp. 2768-2778.

藤田隆史，中嶋一史，杉本一，世古泰朗，小見俊夫，鉛直免震のための振動方向変換機構を用いた三次元免震床 の開発，日本機械学会論文集 C 編，Vol. 56，No. 526（1990)，pp. 1377-1380.

藤田隆史, 余語邦彦, 小見俊夫, 小泉孝之, 直線運動機構を利用した免震装置の研究，日本機械学会論文集 C 編, Vol. 50, No. 456 (1984), pp. 1339-1350.

深沢剛司，藤田 聡，倉林 浩，木下明洋，コイルばねを鉛直設置した免震装置に関する研究（第 1 報・第 2 報）, 日本機械学会論文集 C 編，Vol. 74，No. 739 (2008)，pp. 506-520.

古平有一，大亦絢一郎，田口基之，下坂陽男，下田博一，水平半円弧ばねと磁気減衰を用いた免震・防振テーブ ルの研究，日本機械学会論文集 C 編，Vol. 71，No. 702 (2005)，pp. 434-441.

大亦絢一郎，近藤洋文，下坂陽男，下田博一，X-Y テーブルとうず巻ばねを用いた免震テーブルの研究，日本機 械学会論文集 C 編，Vol. 68，No. 667 (2002)，pp. 786-792.

新谷真功, 田口直矢, 服部雄一, 摩擦による免震装置の相対変位低減に関する実験的研究, 日本機械学会論文集 C 編，Vol. 73，No. 734 (2007)，pp. 2684-2689.

Takahashi, K., Inoue, K., Kato, A., Morishita, M. and Fujita, T., Development of three-dimensional seismic isolation for power plant, Proceedings of 9th World Seminar on Seismic Isolation, Energy Dissipation and Active Vibration Control of Structures, Vol. II (2005), pp. 177-184.

上田誠治，大亦絢一郎，山岸亮平，横尾淳一，バイリニア形ばね特性をもつ上下および三次元免震テーブル（ハ の字形リンク機構を用いた場合)，日本機械学会論文集 C 編，Vol.73，No.735（2007），pp. 2932-2939.

上田智士, 秋元将男, 榎本孝雄, 藤田隆史, 美術品用転がり形免震装置の研究, 日本機械学会論文集 C 編, Vol. 71, No. 703 (2005), pp. 807-812.

若林信宏, 萩原哲夫, 堀端明雄, 佐藤千助, 朝日崇, 大亦絢一郎, 長周期地震動を考慮した免震テーブルの開発, 日本機械学会論文集 C 編，Vol.77，No. 783 (2011)，pp. 4090-4099.

若林信宏, 増田 剛, 大亦絢一郎, 下坂陽男, $\mathrm{V}$ 形リンク機構を用いた上下免震装置の設計法と三次元免震テーブ ルへの応用，設計工学，Vol. 45，No. 3 (2010a), pp. 148-157.

若林信宏, 齋藤宏和, 大亦絢一郎, 下坂陽男, 免震テーブル用漸硬型摩擦ダンパの研究, 設計工学, Vol. 45, No. 5 (2010b), pp. 247-255.

\section{References}

Fujita. S., Morikawa, Y., Shimoda, I., Nagata, S. and Shimosaka, H., Isolation system for equipment using friction pendulum bearings : 1st report, shaking table tests and response analysis on isolated equipment, Transactions of the Japan Society of Mechanical Engineers, Series C, Vol. 59, No. 557 (1993), pp. 11-16 (in Japanese).

Fujita, T., Kuramoto, S. and Omi, T., A three-dimensional earthquake isolation device, Transactions of the Japan Society of Mechanical Engineers, Series C, Vol. 51, No. 471 (1985), pp. 2768-2778 (in Japanese).

Fujita, T., Nakajima, K., Sugimoto, H., Seko, Y. and Omi, T., A 3-dimensional seismic isolation floor using a conversion mechanism of vibration direction for vertical isolation, Transactions of the Japan Society of Mechanical Engineers, Series C, Vol. 56, No. 526 (1990), pp. 1377-1380 (in Japanese).

Fujita, T., Yogo, K., Omi, T. and Koizumi, T., An earthquake isolation device using linear motion mechanism, Transactions of the Japan Society of Mechanical Engineers, Series C, Vol. 50, No. 456 (1984), pp. 1339-1350 (in Japanese). 
Fukasawa, T., Fujita, S., Kurabayashi, H and Kinoshita, A., Study of earthquake isolation system using vertically utilized coiled springs : 1st report, 2nd report, Transactions of the Japan Society of Mechanical Engineers, Series C, Vol. 74, No. 739 (2008), pp. 506-520 (in Japanese).

Kodaira, Y., Ohmata, K., Taguchi, M., Shimosaka, H. and Shimoda, H., A study of an isolation table using horizontal circular arc springs and magnetic damping, Transactions of the Japan Society of Mechanical Engineers, Series C, Vol. 71, No. 702 (2005), pp. 434-441 (in Japanese).

Ohmata, K., Kondo, H., Shimosaka, H. and Shimoda, H., A study of an isolation table using an x-y table and spiral springs, Transactions of the Japan Society of Mechanical Engineers, Series C, Vol. 68, No. 667 (2002), pp. $786-792$ (in Japanese).

Shintani, M., Taguchi, N. and Hattori, Y., Experimental study on isolation device for decrease of displacement by using control of friction, Transactions of the Japan Society of Mechanical Engineers, Series C, Vol. 73, No. 734 (2007), pp. 2684-2689 (in Japanese).

Takahashi, K., Inoue, K., Kato, A., Morishita, M. and Fujita, T., Development of three-dimensional seismic isolation for power plant, Proceedings of 9th World Seminar on Seismic Isolation, Energy Dissipation and Active Vibration Control of Structures, Vol. II (2005), pp. 177-184.

Ueda, M., Ohmata, K., Yamagishi, R. and Yokoo, J., Vertical and three-dimensional seismic isolation tables with bilinear spring force characteristics : for which a $\Lambda$-shaped link mechanism is used, Transactions of the Japan Society of Mechanical Engineers, Series C, Vol. 73, No. 735 (2007), pp. 2932-2939 (in Japanese).

Ueda, S., Akimoto, M. Enomoto, T. and Fujita, T., Study of roller type seismic isolation device for works of art, Transactions of the Japan Society of Mechanical Engineers, Series C, Vol. 71, No. 703 (2005), pp. 807-812 (in Japanese).

Wakabayashi, N., Hagiwara, T., Horibata, A., Sato, S., Asahi, T. and Ohmata, K., Development of seismic isolation table taking account of long-period seismic ground motions, Transactions of the Japan Society of Mechanical Engineers, Series C, Vol. 77, No. 783 (2011), pp. 4090-4099 (in Japanese).

Wakabayashi, N., Masuda, T., Ohmata, K. and Shimosaka, H., Design of vertical seismic isolation system using v-shaped link mechanisms and its application to three-dimensional seismic isolation table, Journal of Japan Society for Design Engineering, Vol. 45, No. 3 (2010a), pp. 148-157 (in Japanese).

Wakabayashi, N., Saito, H., Ohmata, K. and Shimosaka, H., Study on hardening type friction dampers for seismic isolation tables, Journal of Japan Society for Design Engineering, Vol. 45, No. 5 (2010b), pp. 247-255 (in Japanese). 